\title{
The fictitious commodification of money and the Euro experiment
}

\author{
Maja Savevska (maja.savevska@nu.edu.kz) \\ Nazarbayev University, Kazakhstan
}

This paper examines money, the least theorized of Polanyi's fictitious commodities, whose value to human's livelihood warrants extensive regulatory oversight in the price-setting mechanism. In doing so, it contributes to the scholarship that explores the variegated nature of countermovements which can be engendered by unforseen agents deploying various means, often market-based. In light of extensive central bank intervention in the economy, Polanyi's claim about the fictitious character of money deserves credence. This paper argues that the non-conventional policy instrument of quantitative easing in the Eurozone serves the function of protecting society from the commodity fiction of money. The ECB's lender of last resort function is a quintessential counter-measure akin to those extended to labour and land. Yet, despite its protective disposition, the ECB's involvement in managing the currency does not engender a double movement, it rather faces political limits in engendering indiscriminate macro-economic stabilization across an increasingly polarized monetary union.

Keywords: Polanyi, European Central Bank, Monetary Policy, Countermovements, Fictitious Commodities

\section{Introduction}

Polanyi's double movement thesis has been up for grabs lately (Dale, 2010). The uncanny resemblance between laissez-faire capitalism and the current neoliberal predicament resulted in a frequent recourse to Polanyi's (1944) famous double movement thesis, the process of creating a market economy and the countermovement for social protection against such marketization. His critique of the market society resonates well with many social scientific disciplines. Scholars have used his concepts to make sense of various contemporary developments such as the institutional changes of the welfare state in twentieth century (Blyth, 2002), de-globalization dynamics such as Brexit (Hopkin, 2017), European regional integration (Caporaso \& Tarrow, 2009; Hettne, 1994), various labour struggles (Burawoy, 2010; Dale, 2012; Silver \& Arrighi, 2003), agrarian countermovements (Vicki, 2005), twentieth-first century deregulation measures (Buğra \& Ağartan, 2007) etc.

One Polanyian concept that has enjoyed a steady contemporary relevance is fictitious commodities which denote those aspects of life such as land, labour and money that have been turned into mere objects of commerce governed by market prices (Dale, 2010). According to Polanyi, only in the market economy, governed by the idea of the self-regulating market, any interference with the adjustment of prices in these three domains is prohibited. Polanyi saw the commodification of land, labour and money as fictitious because beyond their exchange value they have wider use value. Any attempt to create a self- 
regulating market of these three commodities results in inevitable countermovements aimed at safeguarding the functions of these core elements of people's livelihood. From the three fictitious commodities, it is labour that has been most widely theorized and applied to contemporary developments in global labour relations. For decades, the commodification of labour has been a reference point in the scholarship on the welfare state; both in those who purport that the welfare state has undergone a restructuring along neoliberal lines, despite the lack of its total retrenchment (Höpner \& Schäfer, 2010; Cafruny \& Ryner, 2007; Belfrage \& Ryner, 2009), and in those who find evidence of decommodifying tendencies in various social policy measures that increase the welfare of workers (Birchfield, 2005; Esping-Andersen, 1990; Caporaso \& Tarrow, 2009). Land politics has gotten a somewhat reduced scholarly scrutiny. Few notable contributions are those of Debbie Becher (2014) and Christopher Rea (2017) who focus on the micro-foundations of various countermovements aimed at preserving the land's use value all the while relying on market-based instruments.

While Polanyi's critique of the fictitious commodification of labour and land has enjoyed stable interest, his equally perspicacious insight into the fictitious nature of money has not received the attention it deserves. Two honorable exceptions are Hadrien Saiag (2014) and Chrostopher Holmes (2014). Saiag (2004) masterfully reformulated Polanyi's critique of Welrasian theory of money; yet even so his contribution is focused on understanding the various functions of money rather than the new practices of monetary governance that underscore the fictitious nature of money. Holmes (2014) goes a little further in his empirical application of Polanyi's concepts by examining how the conflicts between the various functions of money relate to the Eurozone crisis. This paper follows their lead and tries to fill a gap by bringing scholarly attention to an area of interest that has been neglected by the resurgent Polanyian scholarship. Namely, I examine Polanyi's writings on money that enables us to generate a valuable insight into modern day central banking practices. I argue that Polanyi's arguments about the fictitious character of money are relevant to contemporary central bank interventions and they need to be integrated into a Polanyian framework for the twentieth-first century. After all, it is in the money market that we saw the recent and most far-reaching breakdown of the market economy. In doing so, I contribute to the scholarship that argues that protectionist counter-moves come not only from various agents, but also via various means, often market-based (Rea, 2017; Savevska, 2014).

The paper is divided in six parts. Following the introduction, the subsequent sections introduce Polanyi's main thesis and his thoughts on money and central banking. The paper then articulates a Polanyian reading of a new empirical phenomenon, namely the European Central Bank's unconventional monetary policy. Following a brief explanation of the Eurosystem's operations, the paper discusses the ECB's quantitative easing measures, the protection they furnish to the productive organizations, and their political limits in engendering indiscriminate macro-economic stabilization across an increasingly polarized monetary union. The paper concludes by arguing that although the ECB's unconventional measures protect the purchasing power of money from the market mechanism, they do not constitute a turn towards a fully-fledged countermovement.

\section{Polanyi's core thesis}

Karl Polanyi (1944) is best-known for his book, The Great Transformation (TGT), wherein he develops an unconventional narrative about the fascist crisis of the twentieth century, whose root he claims need to be traced back to Ricardian England. His double movement thesis represents a critical appraisal of the institutional transformation that constituted laissez-faire capitalism of the nineteenth century (Dale, 2010; Gemici, 2008). By bringing forward evidence that demonstrates the constructedness of the market society, he 
debunked the neoclassical economics view that the market emerges out of human's natural inclination for barter (Inayatullah \& Blaney, 1999). Instead, he went at some length in trying to show how the idea of the self-regulating market gained predominance, thanks to particular state actions that brought forward the commodification of land, labour and money (Block, 2003). By transcending the conventional class struggle narrative, Polanyi asserted that the commodification of fictitious commodities instigated a countermovement that aimed to preserve the livelihood of humanity and nature through social protections against marketization - the second step of the double movement (Birchfield, 2005; Munck, 2006). ${ }^{1}$ In TGT, the narration of the development of laissez-faire capitalism is imbued with a nuanced observation of the complex interaction between the measures that constituted the disembedding and embedding tendencies. Therein, Polanyi (1944) presents us a reality constituted by a complex dialectic between the acts that disembedded the economy, such as the enclosure acts and the repeal of the Poor Laws, and the protective anti-enclosure measures.

Polanyi $(1944,138)$ saw the double movement as a product of a dialectics between two principles of institutional organization, each supported by particular social actors relying on different means (Streeck, 2011). One was the improvement principle of economic liberalism, 'aiming at the establishment of a self-regulating market, relying on the support of the trading classes, and using largely laissez-faire and free trade as its methods; the other was the habitation principle of social protection aiming at the conservation of man and nature as well as productive organization, relying on the varying support of those most immediately affected by the deleterious action of the market - primarily, but not exclusively, the working and the landed classes - and using protective legislation, restrictive associations, and other instruments of intervention as its methods' (Polanyi, 1944, 138). The strength of Polanyi's analysis rests in his invention of two principles, improvement and habitation, and his idea of how they contingently interacted to produce what was known as a laissez-faire capitalism. Polanyi (1944) used these two principles to denote the deliberate measures that improved the tools of production and those that dealt with the ramification of such improvement respectively. In his analysis, he made it explicit that the unfolding of economic liberalism was instantaneously followed by social protection. Contrary to the 'belief in spontaneous progress,' Polanyi $(1944,39)$ underscored the role of government in the extension of both the improvement and the habitation principles. By tracing the historical genesis of the market society, Polanyi (1977) observed that the commodification of land and labour, which was secured through the enclosure movement that created competitive markets for land and labour, engendered counter-measures aimed at securing the well-being of the labour force. The self-protection of society arose as an imperative only in the context of commodification. He identified the labour movement during the industrial revolution as a corollary to the deliberate measures that introduced competitive labour markets (Polanyi, 1944, 73). A similar dynamic can be observed in the enactment of the anti-enclosure policy by the Tudors and Stuarts aimed at curtailing the profit orientation in the market for land.

Polanyi identified land, labour and money as being fictitious commodities because their production is not made for sale (Birchfield, 2005). Land is another word for nature, labour

\footnotetext{
${ }^{1}$ In his last book, The Livelihood of Man, Polanyi took it upon himself to recast the scope of the neoclassical economic inquiry that was merely concerned with the issues of economising and allocating scarce resources. Instead he advocated a reorientation of economic theory towards the livelihood of man, which depends on nature and his fellow humans. 'To study human livelihood is to study the economy in this substantive sense of the term' (Polanyi, 1977, 20). After careful consideration, I decided to replace the term 'livelihood of man' with 'people's livelihoods' in order to avoid the risk of being blamed for reproducing gendered categories, all the while maintaining the exact meaning of the concept that Polanyi had in mind. I would like to thank Lisa Tilley for bringing this to my attention. Polanyi himself used the terms interchangeably and basic 'find function' in the pdf version of his book shows that he used the term human economy, society, race, and livelihood more than 'man's livelihood'.
} 
is just one aspect of the human nature, and money is not a commodity, but purchasing power, whose existence depends on central banking. Polanyi (1944) criticised this reductionist view of land, labour and money present in both classical and neoclassical economics. The attempt to create free market for these fictitious commodities was 'the weirdest of all undertakings of our ancestors' (Polanyi, 1944, 187), which tends to produce dislocations that result in crisis i.e. countermovements.

\section{Polanyi's view on money}

Polanyi published on a wide-range of topics from the developments of the market society in nineteen century England, to various institutional orderings of the economy in pre-capitalist societies (Champlin \& Knoedler, 2004). In addition to conceptually separating the market from trade, Polanyi $(1957 ; 1977,123)$ drew a line between money and markets. Contrary to orthodox thinking, he asserted that money is not a commodity, but it is an institution concerned with debt obligations; hence his reflections resemble the institutionalist accounts of American economist and sociologist Thorstein Veblen and John R. Commons, the founder of labour economics (Maucourant \& Plociniczak, 2013; Baker \& Widmaier, 2014). ${ }^{2}$ By analysing the different functions of money (all-purpose money vs. special purpose one), Polanyi (1977) was able to demonstrate how in pre-capitalist societies money was not governed through the principle of exchange, but through norms of reciprocity. He noted how money used in pre-capitalist societies 'was not a means of exchange, it was a means of payment; it was not a commodity, it was purchasing power' (Polanyi, 1944, 205), usually associated with status and rank. Money in pre-modern societies did not have usefulness in itself, but was used for purchasing products, whereas in the market society money is transformed into a sought after commodity. ${ }^{3}$

His historically grounded assertion that money predates the market, which is further supported by recent research on the origin of money (see Desan, 2014; Peacock, 2004; 2006), stands in contrast to the orthodox view that holds that barter produces money and the different functions of money (unit of account, means of payment and store of value) follow from its function as a medium of exchange. By studying the special-purpose money from early periods, Polanyi $(1957,264)$ saw the flaws in the catallactic view that sees money as a neutral medium of exchange. He showed how the other functions of money, such as unit of account, and means of payment do not derive from the market, but from 'definite uses' (Polanyi, 1957, 264). By recognising the role of the state in monetising the economy, Polanyi (1977) criticised the catallactic view because of its inability to factor central banking into the concept of money, which is especially pertinent today given the significant role central banks play in stabilizing the economy.

The role of the state was not only crucial to the development of the market for land and labour, but also for money (Peacock, 2004; 2006). The central role of public authorities' management of the economy is most evident in the supply of credit. Polanyi's famous study of the Gold Standard demonstrates the tension engendered by attempts to create a self-regulating global marketplace whereby domestic priorities of macroeconomic stability are subordinated to international currency stability. Although he is wrongly accused by Knafo (2013) for portraying the Gold Standard as a liberal monetary regime that kept states accountable to the market, Polanyi, on the contrary, underscored the importance of

\footnotetext{
2 However, there is difference between Polanyi and the institutionalists (See Watson, 2005).

${ }^{3}$ An interesting parallel emerges between Polanyi and Marx. Marx $(1906,165)$ makes a distinction between two forms of circulation: C-M-C, where commodities are transformed into money and again into commodity, and M-C-M, where money is transformed into commodities and into money again (buying for the sake of selling). It is the latter case that transforms money into capital. In the former case the goal of the circulation is commodity, in the latter it is money itself.
} 
domestic monetary politics that 'reduced the automatism of the gold standard to a mere pretense' (Polanyi, 1944, 204).

Central banking practices are in effect protective measures aimed at insulating the business enterprises from the vicissitudes of the Gold Standard that automated the adjustment of balance of payments among countries. ${ }^{4}$ Central banks played a key mediating role between the commodity standard's imperative of maintaining currency convertibility and the productive sector's need for elastic credit creation (Block \& Sommers, 2014). Countries were supposed to play by 'the rules of the game' in order to eliminate balance of payments imbalances, which meant deficit countries should increase interest rates and reduce the money supply via open market operations and vice versa in surplus nations. Nonetheless, the discount rate and the open market operations of central banks aimed to reduce the deleterious effect of the inevitable deflationary pressure. Whether due to the expansion of suffrage (Eichengreen, 1996) or overly independent central banks (Simmons, 1996), monetary policies often responded to the needs of the domestic business cycle rather than let the automatic adjustment expected under the Gold Standard occur. Central bank policy that governed the domestic circulation of token money (fiduciary) i.e. the supply of credit, often responded to political needs rather than external pressures of capital flows. Domestic price stability was priority. Despite its pretence of automatism, the Gold Standard was not self-executing.

Allowing the price mechanism to determine the supply and demand for commodities produced for sale leads to correction of the disequilibrium. However, with fictitious commodities, increases in supply or demand cannot always happen without hurting the bearers of these commodities which have use values beyond their exchange values. In the case of money, deflationary pressures have deleterious consequences on all productive organizations. Commodity money, such as gold, with its inevitable scarcity, is not compatible with expansion of production engendered by the industrial revolution. The increase in productive capacity engendered the creation of money, which was not subject to the automatic market adjustment mechanism, but to steering mechanisms governed by central banks (Polanyi, 1944, 202).

Contemporary monetary policy instruments demonstrate the continued relevance of Polanyi's notion of the fictitious character of money. I argue that the European Central Bank's unconventional monetary policy measures, its asset purchase programs, most accurately capture the limits of the self-regulating market. The lender of last resort function performed by the ECB via its quantitative easing (QE) program, is a contemporary example of protection that showcases the utopian nature of the benefits of undisturbed market mechanism. If left undisturbed, the market administration of purchasing power, solely governed by periodic shortages or surfeits of money, would have obliterated the productive capacity of the Eurozone.

The perspicacity of Polanyi's remarks is seen not only in his observation that some counterstruggles can be reactionary as was the case with the fascist movements in the 1930s (Block, 2012), but also in his conclusion that the resistance to the perils of the marketcontrolled economy comes from a variety of agents; in the case of the Eurozone the protection is supplied by its central bank. However, despite its core protective function of providing liquidity during crises and stabilizing market expectations, the ECB's quantitative easing measures are not without challenges. The next section of the paper explores the drawbacks of the continued centralization of a key monetary function at the European Union level. Within the currency union, the cost of internal adjustment of prices might be too high to bear and impossible to maintain in an increasingly polarized polity.

${ }^{4}$ Gold Standard was an international monetary system of fixed-exchange rates. 


\section{The Eurosystem}

The Economic and Monetary Union (EMU) is not an overnight project, rather, it has a long history of macro-economic stabilization efforts. Both the EMU and its predecessors, the 'Snake in the tunnel-system' in the 1970s with its band of fluctuations and the European Monetary System I, with its Exchange Rate Mechanism based on European Currency Unit, represent a policy response to the problem of exchange-rate volatility brought about by the breakdown of the Bretton Woods system (Bache et al., 2011; Cafruny \& Ryner, 2007). Given the negative prior experience of floating exchange rates and the competitive devaluations it engenders, European policy makers as early as the 1960s with the Warner Report started making plans for a commitment device that would stabilize intra-EU trade (Eichengreen, 1996). The Delors Report in 1989, with its three stage EMU completion plan, was influenced by the new monetarist thinking that gave credence to the idea that the use of exchange rate as a shock absorber is overrated and devaluations in the long-run are suboptimal because they increase the price of imported goods and raise the costs of the inputs in the production which, in turn, provokes a demand for higher domestic wages and leads to competitiveness problems (Hix \& Høyland, 2011).

The Maastricht Treaty finally constitutionalized the idea of European monetary integration and member states irrevocably gave up their ability to set their own interest rates and pursue devaluations. A new monetary authority was created, the Eurosystem comprising of a newly created central bank, the European Central Bank (ECB) and the national central banks. However, this constitutionally independent central bank, the ECB, was barred from performing one core task, the lender of last resort function, because the Maastricht Treaty specifically outlawed the monetary financing of deficits (article 123) on the insistence of Germany which feared the EMU would generate perverted incentives among some sovereigns which remained in control of their banking and fiscal policies (Buti \& Carnot, 2012; Chang, 2016).

The Eurozone crisis exposed an asymmetry in the monetary policy domain generated by the prohibition of monetary financing. Although we have a common EU policy and central bank, its key lender of last resort function was legally challenged, first for its Outright Monetary Transaction programme and later for its quantitative easing (QE) operations (Brunnermeier, James \& Landau, 2016). Unlike its peers, the ECB was delayed in implementing $Q E$ via its sovereign bond Purchase Programmes (PP), ${ }^{5}$ and moreover its QE had to meet a number of conditions, such as the limit of purchases per issuer and issue share, which was increased from $25 \%$ to $33 \%$ (ECB/2015/10).

Like most modern central banks, the ECB is granted constitutionally-backed independence in pursuing its core objective of price stability. But it is in the aftermath of the crisis that the ECB started to perform yet another key function as lender of last resort, which was not fully exercised before 2012, even though the ECB was engaging in non-standard monetary measures such as the Securities Market Program, covered bond purchase program, and fixed-rate full allotments (See Cour-Thimann \& Winkler, 2012 for details). Unlike European politicians, the ECB played a more crucial role in saving the Euro by increasing liquidity via various instruments, such as long term refinancing operations (LTFO), targeted long term refinancing operations (TLTFO), and various asset purchase programmes (Schmidt, 2014). These terms, which have a veneer of technocratic complexity, refer to a straightforward practice of providing long-term funding with attractive conditions to credit agencies via the Eurosystem. The recognized hope here is that by providing a cushion of liquidity for banks holding illiquid assets, the process will, on the one hand provide alternative source

\footnotetext{
${ }^{5}$ The QE refers to the sovereign bonds PP which started in 2015, but we have to note that the ECB has other PP, such as covered bonds PP implemented in 2009, 2011 and 2014, asset-backed securities PP initiated in 2014, and the more contentious corporate bonds PP which started in 2016, thanks to which its balance sheet ballooned to almost $€ 4$ trillion.
} 
of funding to the impaired interbank lending and, on the other hand ease private sector credit conditions and stimulate bank lending to 'the real economy'. ${ }^{6}$

\section{The ECB's lender of last resort function}

The ECB conducted its first LTROs with a three year maturity in December 2011 (Brunnermeier, James \& Landau, 2016; Chang, 2016). ${ }^{7}$ The LTROs were followed by TLTROs I with a longer four year maturity starting in June 2014 and TLTROs II starting in March 2016 (the last consignment of the TLTROs was issued in March 2017). In the context of a driedup interbank system, the LTROs, which totalled $€ 1$ trillion, together with the TLTROs provided liquidity to the troubled Eurozone banks (Gros, 2012). In addition to its open market operations, ${ }^{8}$ the ECB has conducted various asset purchase programmes (PP), the so-called outright operations such as the three covered bond PPs which started in 2009, 2011 and 2014 respectively, the asset-backed securities PP which started in November 2014, the sovereign bonds PP which started in March 2015, and corporate bonds PP which started in June 2016. ${ }^{9}$ Thanks to these quantitative easing measures, the balance sheet of the ECB has reached around $€ 4$ trillion. ${ }^{10}$ Besides its $Q E$, the ECB committed itself to buy an unlimited amount of sovereign debt under the Outright Monetary Transactions (OMT) program that was announced in 2012 and has not been initiated yet since it passed the judicial hurdles (Chalmers, Jachtenfuchs \& Joerges, 2016).

Much like during the Gold Standard and the Bretton Woods System, central banks today continue to provide a key function of maintaining the purchasing power of money. In the case of the ECB that role is especially pertinent due to the structural capacity gap, whereby monetary policy is centralized at a federal level while fiscal policy in the aftermath of the crisis has constitutionalized a consolidation state that leads to permanent redefinition of the fiscal capacity of member states (Haffert \& Mehrtens, 2015; Braun \& Hubner, 2018). The quantitative easing measures which furnish protection to business organizations demonstrate that the idea of the self-regulating market can never be fully realized. The central bank's involvement in managing the currency, which is a form of social protection par excellence, akin to the habitation measures extended to labour and nature, points to the fictitious nature of money as a commodity.

Like all matters of policy, this peculiar domain is imbued with internal political contestations, yet unlike the other two fictitious commodities (labour and land), the 'saving' of money from the whims of the self-regulating market enjoyed a broad consensus among the policy-making community. The urgency that we see in saving the money market is nowhere to be found when it comes to saving the environment or labour from degradations caused by the market mechanism. The central bank money injected into the market for liquidity as a way of offsetting the liquidity pull-back, resulted in an expansion of the central bank's balance sheet of up to $€ 4$ trillion. A public backstop of the money markets was provided early on during the crisis in the form of full allotment in its open market operations and later on in the form of the assets purchase programs. This protection of business

\footnotetext{
${ }^{6}$ The language of 'the real economy' comes directly from the ECB's website describing the purpose of TLTROs. See European Central Bank (2014) ECB announces monetary policy measures to enhance the functioning of the monetary policy transmission mechanism. June 5. Available from: https://www.ecb.europa.eu/press/pr/date/2014/html/pr140605_2.en.html.

${ }^{7}$ European Central Bank (2011) ECB announces measures to support bank lending and money market activity. December 8. Available from: www.ecb.europa.eu/press/pr/date/2011/html/pr111208_1.en.html.

${ }^{8}$ For the specificities of the ECB's open market operations that consist of lending funds to banks which post sovereign bonds as collateral, unlike the Federal Reserve that buys T-bills outright, see Bagus (2012).

${ }^{9}$ www.ecb.europa.eu/mopo/implement/omt/html/index.en.html. It has to be noted that the public sector PPs comes with some unfortunate strings attached, such as the $33 \%$ limit of purchases per issuer and issue share.

${ }^{10}$ Its $€ 80$ billion monthly purchases of public and private bonds in late 2015 and 2016 were scaled back to $€ 60$ billion in 2017.
} 
and employment via monetary means, showcases the variety of ways and actors involved in taming the operation of the self-regulating market.

The crisis created opportunity for a correction of the asymmetry in the monetary portfolio because, at the simplest level, the performance of the central bank's core function of providing liquidity to the economy was needed for the stabilization of market expectations (Brunnermeier, James \& Landau, 2016). Yet, there are some drawbacks of the continued centralization of monetary authority in a politically contested and polarized monetary union. The ECB yields great unchecked discretionary authority with immense distributive potential, deciding when and how to exercise its lender of last resort function. The ECB can choose to cut off a specific national banking system from its liquidity provisions for political ends and consequently cut the financing of the respective government. It can wield this power through various means. First, through its collateral framework it can make margin calls (Nyborg, 2017), ${ }^{11}$ raise haircuts or even reject certain sovereign bonds as collateral, ${ }^{12}$ both of which were common pro-cyclical practices during the crisis (Gabor \& Ban, 2016). Second, it can refuse to purchase certain sovereign bonds under its Public Sector Purchases Programmes, which the ECB threatened to use in order to nudge the Italian Prime Minister Berlusconi into action (Chang, 2016, 85)..$^{13}$ Third, it can decline to engage in future OMT unless the affected government has accepted its terms of financing. And finally, it can choose corporate winners via its corporate purchase programmes.

The ECB has the power to transform information-insensitive sovereign debt into information-sensitive debt and bring a member state to a brink of involuntary default in a context of dried-up interbank credit lines and shrinking deposit base, as was the case with Greece in 2015. The wilful cessation of liquidity provisions to Greek banks in 2015 following the decision of the left-wing Syriza government to call a referendum on the bailout terms is a worrying display of brute economic might on the part of the ECB, rather than a rational economic objective. What ensued from the suspension of Greek banks from the Emergency Liquidity Assistance was capital controls, and there is little legal guarantee that the ECB will not once again arbitrarily curtail market confidence in some member states that have fallen out of favour because monetary affairs has been successfully framed as operating in an apolitical realm. It remains to be seen how exactly this scaling-up of prerogatives will make the EMU more embedded in the Polanyian sense. No provision in the existing rulebook guarantees that the ECB will indiscriminately generate market confidence in all member states, some of which already became victims of the improvement that centralization of rule-making was supposed to furnish.

Besides the above concerns of how the ECB exercises its lender of last resort function within its monetary portfolio, there are two issues that deserve attention. The first issue arises from the latest acquisition of banking supervisory powers introduced with the postcrisis reforms of the EMU governance, which puts the ECB within the newly created Single Supervisory Mechanism (Chang, 2016, 72). ${ }^{14}$ An eventual conflict might emerge between

\footnotetext{
${ }^{11}$ Central bank collateral frameworks are legal instruments that stipulate the type of eligible collateral that credit institutions can use to obtain central bank money. See Gabor and Ban (2016) for details.

12 Haircut is the difference between the market value of the collateral and the collateral value of the collateral (the amount of money lend to the credit institution against that collateral). Nyborg $(2017,208)$ notes haircuts in the Eurosystem are not market determined but by the ECB, all the while haircuts on the secondary market are taken form the collateral framework of the Eurosystem.

${ }^{13}$ A confidential letter sent by the ECB to the then Prime Minister of Italy was leaked in the media disclosing the central bank's strong encouragement for structural reforms of Italy's stagnant economy in the wake of the spike of the Italian bond yields. A confidential letter of similar content was sent to the Spanish government a month before in August 2011. For details on this incident see: Financial Times (2011) ECB letter shows pressure on Berlusconi. September 29. Available from: https://www.ft.com/content/3576e9c2-eaad-11e0-aeca-00144feab49a.

${ }^{14}$ ECB directly supervises 128 Eurozone credit institutions which hold $80 \%$ of the Eurozone assets (Howarth \& Quaglia, 2016, 93).
} 
the ECB's core function of maintaining price stability, which might require setting interest rate policies that are not favourable for banks with solvency issues. The second issue likewise calls into question the ECB's core priority of maintaining price stability and its involvement in the troika's assistance lending which can be a source of conflict (Pisani, Ferry, Sapir \& Wolff, 2013, 110). Additionally, the ECB's denial of access to information to the European Court of Auditors further demonstrates the lack of transparency in the decision-making processes. ${ }^{15}$

\section{Double movement?}

Studying the dialectical interplay between the two principles of improvement and habitation as they relate to current monetary practices, yields interesting insights. However, we need to be wary of the tendency in recent scholarship to proclaim the emergence of a double movement in the Eurozone whenever we see the operation of the principle of habitation (Dale, 2012). I put forward a reading of Polanyi (1944) that acknowledges that the habitation measures are immanent to the improvement ones. In his critique of the market society, Polanyi observed that the commodification of land, labour and money, immediately engendered counter-measures aimed at securing the wellbeing of the labour force, the quality of nature and the purchasing power of money.

Yet, the results of the interaction of the two principles cannot be a priori assumed to follow a specific swing order. Social change is contingent on the socio-temporal context, which means that the two principles in nineteenth century England are qualitatively different from the one today. Thus, a proper Polanyian analysis would not simply find evidence of social protection and declare the emergence of a Third Great Transformation, as numerous scholars tend to do (for ex. Becher, 2012; Caporaso \& Tarrow, 2009; Gill \& Cutler, 2014), but would rather evaluate the quality of those measures on their own terms. The mere existence of the habitation principle does not in any way signify the emergence of a double movement. Notwithstanding the common practice of conflating the two, especially with the growing regressive right-wing forces in Europe and Trumpism in the US, we must make a conceptual distinction between them. While the existence of the embedding tendency is indisputable, the double movement is questionable. According to Polanyi (1944, 247248), the double movement forms only when certain conditions are met: a) when the market society 'refuses to function', and b) when a 'revolutionary situation' crystallizes and society tries to escape a compete annihilation by the self-regulating market. So, we have to acknowledge that, if anything, the habitation measures furnished by the ECB's quantitative easing practices have ensured the continued smooth functioning of the money market.

Not only should the two principles of improvement and habitation not be read in a functionalist fashion, but they must not be treated as opposites that annihilate each other. Instead there is dialectic that results in a contingent synthesis of two dynamics (Lacher, 2007). A synthesis does not imply a peaceful coexistence, but it can mean disruptive dialectic. A balanced unity is not necessarily the end result. The sublation of a contradiction does not automatically follow from the mere recognition of the contradiction (Brincat, 2011). We should not glorify the operation of the principle of habitation because its existence does not transcend the fictitious commodification (Lacher, 1999; Watson, 2014). Polanyi (1944) does not see the self-protection of society as the ultimate progressive solution, because the need for protection arises only in the context of a self-regulating market. When you take away the fictitious commodities protectionism loses its purpose. The

${ }^{15}$ European Court of Auditors (2017) The Commission's Intervention in the Greek Financial Crisis. Special Report (No. 17). This report examined the effectiveness of the Greek Economic Adjustment Programs which were administered by the so-called troika, the European Commission, the ECB and the IMF. 
progressive possibilities envisioned by Polanyi lie outside the coordinates of fictitious commodification (Dale, 2012; Watson, 2014). However, most of the scholarship tends to forget this important qualification by misidentifying a third countermovement in each instance of a counter-measure and by forgetting that Polanyi was interested in a society whose organisational paradigm transcends the dialectics between the self-regulating market and social protection. Thus, the paper cautions against reading the recent ECB practices of salvaging the economy as constituting a true move towards embeddedness. Streeck (2011) contends that the attempt to reconcile the two principles is utopian in nature and harbours an inherent contradiction as exemplified in the many crises of democratic capitalism, including the recent economic crisis that shows the intensified dialectic between the two principles.

\section{Conclusion}

This paper examined money, the least theorized of Polanyi's fictitious commodities, whose value to human's livelihood warrants extensive regulatory oversight in the price-setting mechanism. Polanyi's claim about the fictitious character of money deserves credence nowadays in the context of extensive central bank intervention in the economy. In the aftermath of the latest episode of global credit squeeze, financial enterprises had to be saved from the undisturbed workings of the market mechanism via the massive injection of central bank money into money markets. This paper tried to show how, much like the conventional central bank policies, such as the open market operations and discount windows (lending facilities), the latest non-conventional policy instruments of quantitative easing in the Eurozone serve the function of protecting society from the commodity fiction of money. Yet, in doing so, the latest embodiment of the principle of habitation does not engender a new double movement. On the contrary, the QE prevented the total annihilation of the market-mechanism.

The Great Recession engendered a substantial transformation of the constitutional order of the Eurozone. Contrary to the expectation that the crisis would trigger a re-embeddedness of markets, we witness the intensification of both rule-based and institutional depoliticization not only in the monetary but also in the banking and fiscal domains. And in doing so, the latest constitution-building efforts reinforce the vertical separation between politics and economics. The monetary, banking and fiscal unions increasingly characterized by a technocratic style of governance are the pinnacle of the disembedding tendency. Market-oriented models of governance that are insulated from democratic accountability or public steering are increasingly functioning as the only game in town. And, although some note that the Eurocrats' dream 'is empirically over and normatively unsustainable' (Chalmers, Jachtenfuchs \& Joerges 2016, 21), the technocratic ethos persists, often giving rise to populist countermovements. 


\section{References}

Baker, A. \& Widmaier, W. (2014). The institutionalist roots of macroprudential ideas: Veblen and Galbraith on regulation, policy success and overconfidence. New Political Economy, 19, 487-506.

Becher, D. (2012). Political moments with long-term consequences. In M.P. Smith and M. McQuarrie (eds), Remaking Urban Citizenship: Organizations, Institutions and a Right to the City, 203-220. London: Transaction Publishers.

Block, F. (2003). Karl Polanyi and the writing of the "Great Transformation". In Go, J. (ed), Political Power and Social Theory, 23, 269-291. Bingley: Emerald Group.

Block, F. (2012). Varieties of what? Should we still be using the concept of capitalism? Political Power and Social Theory, 23, 269-291.

Block, F. \& Somers, M.R. (2014). The power of market fundamentalism: Karl Polanyi's critique. Cambridge, MA: Harvard University Press.

Braun B. \& Hübner M. (2018). Fiscal fault, financial fix? Capital Makrets Union and the quest for macroeconomic stabilization in the Euro area. Competition and Change, 22(2), 117-138.

Brincat, S. (2011). Towards a social-relational dialectic for world politics. European Journal of International Relations, 17, 679-703.

Brunnermeier, M.K., H. James \& J-P. Landau (2016). The Euro and the battle of ideas. Princeton University Press.

Burawoy, M. (2003). For a sociological Marxism: The complementary convergence of Antonio Gramsci and Karl Polanyi. Politics and Society, 31, 193-261.

Burawoy, M. (2010). From Polanyi to Polyanna: The false optimism of Global Labour Studies. Global Labour Journal, 1, 301-313.

Burnham, P. (2011). Depoliticising monetary policy: The minimum lending rate experiment in Britain in the 1970s. New Political Economy, 16, 463-480.

Buti, M. \& Carnot, N. (2012). The EMU debt crisis: Early lessons and reforms. Journal of Common Market Studies, 50(6), 899-911.

Cangiani, M. (2011). Karl Polanyi's institutional theory: Market society and its 'disembedded' Economy. Journal of Economic Issues, 45, 177-198.

Caporaso, J. \& Tarrow, S. (2009). Polanyi in Brussels: Supranational institutions and the transnational embedding of markets. International Organization, 63, 593-620.

Chalmers, D., Jachtenfuchs, M. \& Joerges, C. (eds) (2016). The end of the "Eurocrats" dream: Adjusting to european diversity. Cambridge University Press.

Champlin, D.P. \& Knoedler, J.T. (2004). Embedded economies, democracy, and the public interest. Journal of Economic Issues, 38, 893-907. 
Chang, M. (2016). Economic and Monetary Union. Basingstoke, Hampshire: Palgrave Macmillan.

Cour-Thimann, P. \& Winkler, B. (2012). The ECB's non-standard monetary policy measures: The role of institutional factors and financial structure. Oxford Review of Economic Policy, 28(4), 765-803.

Dale, G. (2008). Karl Polanyi's The Great Transformation: Perverse effects, protectionism and Gemeinschaft. Economy and Society, 37, 495-524.

Dale, G. (2010). Karl Polanyi: The limits of the market. Cambridge: Polity Press.

Dale, G. (2012). Double movement and pendular forces: A Polanyian perspective on the neoliberal age. Current Sociology, 60, 3-27.

Dale, G. (2014). Karl Polanyi in Vienna: Guild socialism, Austro-Marxism, and Duczynska's alternative. Historical Materialism: Research in Critical Marxian Theory, 22, 34-66.

Desan, C. (2014). Making money: Coin, currency, and the coming of capitalism. Oxford University Press.

Eichengreen, B. (1996). Globalizing capital: A history of the international monetary system. Princeton University Press.

Esping-Andersen, G. (1990). The three worlds of welfare capitalism. Princeton, NJ: Princeton University Press.

Gabor, D. \& Ban, C. (2016). Banking on bonds: The new links between states and markets. Journal of Common Market Studies, 54(3), 617-635.

Gemici, K. (2008). Karl Polanyi and the Anatomies of Embeddedness. Socio-Economic Review, 6, 5-33.

Gill, S. \& Cutler, C.A. (eds) (2014). New constitutionalism and world order. Cambridge: Cambridge University Press.

Granovetter, M. (1985). Economic action and social structure: The problem of embeddedness. American Journal of Sociology, 91, 481-510.

Gros, D. (2012). On the stability of public debt in a monetary union. Journal of Common Market Studies, 50(2), 36-48.

Hejeebu, S. \& McCloskey, D. (2004). Polanyi and history of capitalism: Rejoinder to Blyth. Critical Review: A Journal of Politics and Society, 16, 135-142.

Hix, S. \& Høyland, B. (2011). Economic and Monetary Union. In Id. The Political System of the European Union, $3^{\text {rd }}$ edition. Basingstoke, Hampshire: Palgrave Macmillan.

Holmes, C. (2012). Problems and opportunities in Polanyian analysis today. Economy and Society, 41, 468-484. 
Holmes, C. (2014) 'Introduction: A post-Polanyian Political Economy for our times', Economy and Society, 43, 525-540.

Hopkin, J. (2017). When Polanyi met Farage: Market fundamentalism, economic nationalism, and Britain's exit from the European Union. British Journal of Politics and International Relations, 19(3), 465-478.

Höpner, M. \& Schäfer, A. (2010). A new phase of European integration: Organized capitalism in post-ricardian Europe. West European Politics, 33(2), 344-368.

Howarth, D. \& Quaglia, L. (2016). The Political Economy of European Banking Union. Oxford University Press.

Inayatullah, N. \& Blaney, D. L. (1999). Towards an ethnological IPE: Karl Polanyi's double critique of capitalism. Millennium Journal of International Studies, 28, 311-340.

Knafo, S. (2013). The Gold Standard and the paradox of liberal financial governance. In Id. The Making of Modern Finance: Liberal Governance and the Gold Standard. Routledge.

Krippner, G., Granovetter, M., Block, F., Biggart, N., Beamish, T., Hsing, Y. \& O’Riain, S. (2004). Polanyi symposium: A conversation on embeddedness. Socio-Economic Review, 2, 109-135.

Lacher, H. (1999). The Politics of the market: Re-reading Karl Polanyi. Global Society, 13, 313-326.

Lacher, H. (2007). The slight transformation: Contesting the legacy of Karl Polanyi. In Buğra, A. \& Ağartan, K. (eds) Reading Karl Polanyi for the Twenty-First Century: Market Economy as a Political Project, 50-64. New York, NY: Palgrave Macmillan.

Latham, A.J.H. (1997). Karl Polanyi: Some observations. Paper presented at the Global History Seminar at the Institute of Historical Research. Retrieved from: http://sasspace.sas.ac.uk/4396/1/Karl_Polanyi_Some_Observations_by_A._J._H.pdf

Lie, J. (1991). Embedding Polanyi's market society. Pacific Sociological Association, 34, 219-235.

Maucourant, J. \& Plociniczak, S. (2013). The institution, the economy and the market: Karl Polanyi's Institutional Thought for Economists. Review of Political Economy, 25(3), 512-531.

Nyborg, K. G. (2017) Central bank collateral frameworks, Journal of Banking and Finance, 76, 198-214.

Peacock, M. (2004). No methodology without ontology! Reorienting Economics. Journal of Economic Methodology, 11, 313-319.

Peacock, M. (2006). The origins of money in ancient greece: The Political Economy of coinage and exchange. Cambridge Journal of Economics, 30, 637-650. 
Pisani-Ferry, J., Sapir, A. \& Wolff, G.B. (2013). Financial assistant of the Euro area: An early evaluation. Bruegel.

Polanyi, K. [1944] (2001). The Great Transformation: The political and economic origins of our time. Boston: Beacon Press.

Polanyi, K. (1957). The economy as instituted process. In Polanyi, K., Arensberg, C.M. \& Pearson. H.W. (eds) Trade and Market in the Early Empires, 243-270. New York, NY: The Free Press.

Polanyi, K. (1963). Ports of trade in early societies. Journal of Economic History, 32, 30-45.

Polanyi, K. (1977). The livelihood of man, edited by H.W. Pearson. New York, NY: Academic Press.

Polanyi-Levitt, K. (ed) (1990). The life and work of Karl Polanyi. Montreal, Quebec: Black Rose Books.

Popper, K. [1963] (2002). Conjectures and refutations: The growth of scientific knowledge. London: Routledge.

Rea, C. (2017). Theorizing Command-and-Commodity Regulation: The case of species conservation banking in the United States. Theory and Society, 46(1), 21-56.

Saiag, H. (2014). Towards a neo-Polanyian approach to money: Integrating the concept of debt. Economy and Society, 43, 559-581.

Savevska, M. (2014). Polanyian reading of the socio-economic transformations of the European Union. Journal of Contemporary European Studies, 22(4), 395-410.

Silver, M. (1983). Karl Polanyi and the markets in the ancient Near East: The challenge of evidence. Journal of Economic History, 43, 795-829.

Simmons B. (1996). Rulers of the game: Central bank independence during the interwar years. International Organization, 50(3), 407-443.

Spearin, C. (2008). Private, armed and humanitarian? States, NGOs, international private security companies and shifting humanitarianism. Security Dialogue, 39, 363-382.

Streeck, W. (2011). Taking capitalism seriously: Towards an institutionalist approach to contemporary Political Economy. Socio-Economic Review, 9, 137-167.

Vančura, M. (2011). Polanyi's Great Transformation and the concept of the embedded economy. Charles University, IES Occasional Paper, 2/2011.

Watson, M. (2009). 'Habitation versus improvement' and a Polanyian perspective on bank bail-outs. Politics, 29, 183-192.

Watson, M. (2014). The Great Transformation and progressive possibilities: The political limits of Polanyi's Marxian history of economic ideas. Economy and Society, 43, 603-625. 